209. 藤原 洋：イソニコチン酸ヒドラジド誘導体の理化学的研究 (第 4 報) イソニコチン酸ヒドラジド誘導体の水溶液中の化学平衡について その 1

Hiroshi Fujiwara: Physicochemical Studies on Isonicotinoylhydrazine Derivatives. IV. On Equilibrium of Isonicotinoylhydrazine Derivatives in Aqueous Solutions. (1).

(Research Laboratories, Takeda Pharmaceutical Industries, Ltd.)

In order to clarify the equilibrium mechanism of furfurylidene-INAH in aqueous solution, equilibrium constants of furfurylidene-INAH and 1-benzoyl-2-furfurylidenehydrazine in buffer solutions of various $\mathrm{pH}$ were measured. It was found that the variation in the resonance structure of furfurylidene-INAH in acidity had no direct effect on equilibrium constants but an effect on the ionic dissociation constant of its azomethine group.

(Received February 28, 1958)

イソニコチン酸ヒドラジド (INAH) の hydrazone は INAH と同様抗結核剤として有効で, INAH よりも毒 性の少ないことが認められている ${ }^{124)}$ また本品が生体内で分解して INAH を生成することる尾崎によつて明ら かにされ，その抗結核作用と INAH への解離との間に相関関係のあることが容易に推定される。著者は iso・ nicotinoylhydrazone（以下 INAH-hydrazone と略）の水溶液中に拈ける態度を検討し，本物質が水溶液中で加水 分解によつて生じる INAH やカルボニル化合物に対し平衡関係にあることを認め, これらの平衡の機構と生体内 の hydrazone の变化との関係を笕明亦る目的で本研究を行つた。

本報では 1-furfurylidene-2-isonicotinoylhydrazine（furfurylidene-INAH）の水溶液中に拉沪る加水分解の機 構を究明したが，本品には水溶液中で（I）の平衡が考えられる。

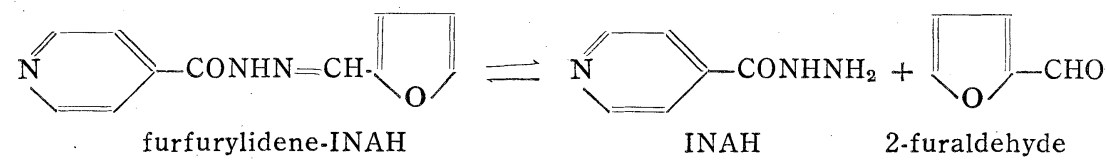

この平衡は hydrazone, INAH がともに塩基であるから溶液の pHにより著しく影響される。すなるら oxime, semicarbazone, hydrazone に括ける液の $\mathrm{pH}$ と平衡恒数の関係についての Conant らう の報告を, furfurylideneINAH に対応させると（I）の平衡に INAH の hydrazine 部㧍よび furfurylidene-INAH の azometine 部の イオン解離の平衡が重なつて平衡恒数 $\mathrm{K}$ と水素イオン濃度との間に (II) 式の関係が成立する。

$$
\mathrm{K}=\mathrm{K}_{0}\left\{1+[\mathrm{H}+] / \mathrm{K}_{\mathrm{A}}\right\} /\left\{1+[\mathrm{H}+] / \mathrm{K}_{\mathrm{S}}\right\}
$$

(II) 式に㧍いて $\left[\mathrm{H}^{+}\right]$は水素イオン濃度を表わし， $\mathrm{K}_{0}$ は $[\mathrm{H}+]$ が極小すなわらイオンの影響のない游離の塩基の間 の平衡恒教である. $\mathrm{K}_{\mathrm{A}}$, $\mathrm{K}_{\mathrm{S}}$ は hydrazine, hydrazone のイオン解離恒数でそれぞれ(III)，(IV) 式で表わされる.

$$
\mathrm{K}_{\mathrm{A}}=\left[\mathrm{RCONHNH}_{2}\right]\left[\mathrm{H}^{+}\right] /\left[\mathrm{RCONHNH}_{i}^{+}\right]
$$

$$
\mathrm{K}_{\mathrm{S}}=\left[\mathrm{RCONHN}=\mathrm{CH}-\mathrm{O}_{\mathrm{O}}\right][\mathrm{H}+] /\left[\mathrm{RCONHNH}+=\mathrm{CH}-\|_{\mathrm{O}}\right]
$$<smiles>[R][n+]1ccccc1</smiles>

一方 INAH は 2 酸塩基でありまた前報で明らかにされたように furfurylidene-INAH に pyridine 部への proton 付加によつて共鳴構造に变化を㳵よ洁から furfurylidene-INAH 和よびその類似化合物の平衡に就い

1) P. P. T. Sah, S. A. Peaples: J. Am. Pharm. Assoc. 18, 513 (1954).

2) 尾崎: 生化学 27,696 (1956).

3) H. H. Fox: Science 116, 129 (1952); 118, 497 (1953)

4) J. Bernstein, et al.: Am. Rev. Tuberc. 65, 357 (1952)

5) J. B. Conant, P. O. Bartlett: J. Am. Chem. Soc. 54, 2881 (1932). 
$て \mathrm{~K}$ と $\left[\mathrm{H}^{+}\right]$の間に Conant の式が成立するか否かは興味深く, furfurylidene-INAH および 1-benzoyl-2-furfurylidene hydrazine について各種水溶液中の平衡恒数を測定し Conant 式からの計算值と比較検討したところ 両者はよく一致し, INAH, benzoylhydrazine 抢よび hydrazone の塩基性について 2,3 の知見を得た。

化学平衡の成立 化学平衡の検討に必要なINAH の定量法についてはすでに 1,2-naphthoquinone-4-sulfonate (NQS) による比色定量法6) を検討したが，平衡の機構を解明するための精密な測定にはな特不充分で方る・著者 は主として呈色液の安定度, 試薬の再検討を行い, 誤差 $1.08 \%$ で定量し得るよう改良した。 また furfurylideneINAH, 2-furaldehyde は定量に何等障害を与えない.

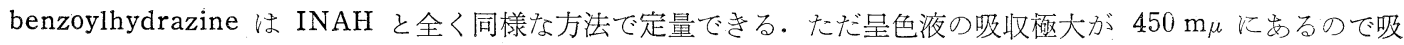
光係数 ( $\varepsilon$-value) をこの波長で測定する必要がある.

化学平衡の成立は一定の条件下に原系, 生成系から出発して常に一定の状態に達し得ることによつて証明し得 る. 著者は furfural, INAH の混合緩衝溶液および furfurylidene-INAH, 1-benzoyl-2-furfurylidenehydrazine の緩衝溶液を恒温に保ち，30 分ないし 1 時間ごとに取り出して INAH または benzoylhydrazine の定量を行つ た。この系が平衡になれば INAH または benzoylhydrazine の定量值は一定值を得るようになる。しかしINAH または benzoylhydrazine の定量のみで緩衝液中の平衡恒数を正しく得るためにはその定量法が反応系に対して INAH, benzoylhydrazine に特異的であることはもちろん, 平衡条件に括いて他の副反応 (主として INAH, benzoylhydrazine, 2-furaldeyde の分解）が生じない場合に沶いて可能である。著者は主として 1 ～の pHで平衡 恒数の測定を行つたので, $\mathrm{pH} 1.20$ 抢よび 5.00 に括ける 2-furaldebyde, INAH および benzoylhydrazine の 安定度を検討した.2-furaldehyde の定量は azotometry によつた (Table I). Table I から㔂定範囲内で， INAH，2-furaldehyde および benzoylhydrazine は何等変化しないことを確かめ得た。

Table I. Stability of INAH, 2-Furaldehyde and Benzoylhydrazine (BH) in 1.20 and 5.00 Buffer Solution at $30^{\circ}$

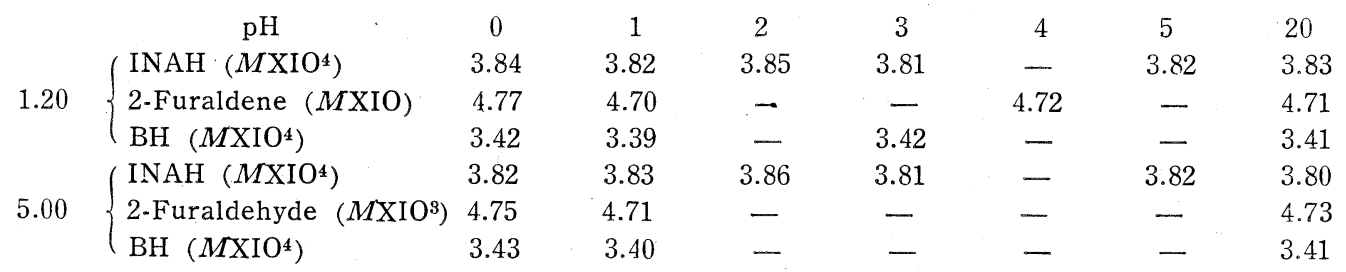

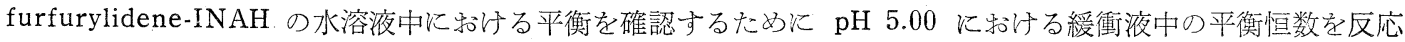
系の濃度を变えて測定した (Table IIa,Table IIb)。平衡に達するまでに約 20 時間を要するので，反応液を一夜

Table IIa. Equilibrium Constant in Hydrolysis of Furfurylidene-INAH in Buffer Solution of Various Concentrations of INAH

INAH concn.

\begin{tabular}{|c|c|c|c|c|c|}
\hline \multirow{2}{*}{\multicolumn{2}{|c|}{$\begin{array}{l}\text { Initial } \\
1.28 \times 10^{-4} M\end{array}$}} & \multicolumn{2}{|c|}{ After equilibrium } & \multicolumn{2}{|l|}{ K } \\
\hline & & 0.28 & $10^{-4} M$ & 1.06 & $10^{-4}$ \\
\hline 1.92 & $" \prime$ & 0.47 & $\prime \prime$ & 1.08 & $" \prime$ \\
\hline 3.84 & $\prime \prime$ & 1.25 & $\prime \prime$ & 1.05 & "l \\
\hline 5.12 & 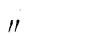 & 2.00 & $\prime \prime$ & 1.06 & $\prime \prime$ \\
\hline
\end{tabular}

Temp. $30 \pm 1^{\circ}, \mathrm{pH} 5.00$. 2-Furaldehyde initial concn. $4.77 \times 10^{-4} M$

Table II b. Equilibrium Constant in Hydrolysis of Furfurylidene-INAH in Buffer Solution of Various Concentrations of Furfurylidene-INAH (FI)

$\begin{array}{ccc}\text { Initial concn. of FI. } & \text { INAH concn. after equilibrium } & \mathrm{K} \\ 0.71 \times 10^{-4} M & 0.49 \times 10^{-4} M & 1.09 \times 10^{-4} \\ 1.42 " \prime \prime & 0.81 " & 1.08 " \\ 2.13 \text { " } & 1.06 " \prime & 1.05 " \\ \text { Temp. } 30 \pm 1^{\circ} & & \end{array}$

6) 藤原： 本誌 $\mathbf{7 6}, 874(1956)$. 
電気恒温器中 $30 \pm 10$ で保存して後, 後述する (実験の部) 方法で平衡恒数を測定した。Table IIa, b で明らか なように平衡恒数 INAH，furfural の混液からもまた furfurylidene-INAH からも同一の值が得られ，しかも反 応系の濃度に測定䉇囲内で関係しない。

1-benzoyl-2-furfurylidenehydrazine もTable III に示すように同一の結果が得られる.

Table III. Equilibrium Constant in Hydrolysis of 1-Benzoyl-2-furfurylidenehydrazine in Buffer Solution of Various Concentrations of Benzoylhydrazine

\section{Benzoylhydrazine concn.}

\begin{tabular}{ccc}
\hline Initial & After equilibrium & $\mathrm{K}$ \\
$2.44 \times 10^{-4} M$ & $0.49 \times 110^{-4} M$ & $0.71 \times 10^{-4}$ \\
$3.25 " \prime$ & $0.78 \prime \prime$ & $0.73 \prime \prime \prime$ \\
$4.06 "$ & $1.14 "$ & $0.72 " \prime$ \\
pH $5.00 \quad$ Temp. $30 \pm 1^{\circ}$ & Initial concn. of 2 -furaldehyde $: 4.77 \times 10^{-4} M$
\end{tabular}

pH と平衡恒数の関係 furfurylidene-INAH, 1-benzoyl-2-furfurylidenehydrazine は $\mathrm{pH}$ によつ平衡に 至るまでの時間，いわゆる反応速度に差がある。平衡恒数の測定で INAH または benzoylhydrazine の定量を時 間ごとに行い，一定の定量值を得ることによつて平衡を確認したのはこの理由による。すなわち furfurylideneINAH に和いて pH 3 以下では測定濃度で棌济 1 時間以内に平衡に達するが 3 以上では数時間を要し, 測定範 囲内では $\mathrm{pH}$ が大きい汪ど見掛けの反応速度は小さくなる (Table IV).

Table IV. INAH Value until in Equilibrium at the Reaction between 2-Furaldehyde and INAH in Buffer Solution

\begin{tabular}{|c|c|c|c|c|c|c|c|c|c|c|c|c|}
\hline Time $\backslash p H$ & & 42 & & .05 & & 60 & & 3.10 & & 3.70 & & 40 \\
\hline $1 \mathrm{hr}$. & 2.21 & $10^{-4} M$ & 1.91 & $10^{-4} M$ & $1.70 \times$ & ${ }^{10-4} M$ & 2.93 & $10^{-4} M$ & $3.62 \times$ & $10^{-4} M$ & 3.80 & $10^{-4} M$ \\
\hline 3 & 2.22 & $"$ & 1.95 & $" 1$ & 1.69 & $n$ & 1.82 & " & 3.01 & " & 3.68 & " \\
\hline 5 & 2.24 & $" \prime$ & 1.90 & $\prime \prime$ & 1.70 & $\prime \prime$ & 1.53 & $" \prime$ & 2.64 & $\prime \prime$ & 3.05 & " \\
\hline 9 & - & & - & & - & & - & & 1.44 & & - & \\
\hline 10 & - & & - & & - & & - & & 1.45 & & - & \\
\hline 13 & - & & - & & - & & - & & - & & 1.45 & \\
\hline 14 & - & & - & & - & & - & & - & & 1.44 & \\
\hline
\end{tabular}

Temp. $30 \pm 1^{\circ} \quad$ Initial concn. of INAH: $3.84 \times 10^{-4} M$

Initial concn. of $2-$ Furaldehyde $: 4.17 \times 10^{-4} M$

Table IV から $\mathrm{pH} 3.70$ では 9 時間 $\mathrm{pH} 4.40$ では 13 時間反応させて始めて平衡になり, 平衡時の INAH 濃 度 $1.45 \times 10^{-4} M$ を得た。

著者は各 $\mathrm{pH}$ について 4 回くり返して平衡恒数を測定した (Table V).

Table V. Relationship between $\mathrm{pH}$ and $\mathrm{K}$ in Furfurylidene-INAH in Buffer Solution

\begin{tabular}{|c|c|c|c|c|}
\hline $\mathrm{pH}$ & \multicolumn{4}{|c|}{$\mathrm{K}\left(\times 10^{-4}\right)$} \\
\hline 1.42 & 3.52 , & 3.52 , & 3.56 , & 3.6 \\
\hline 2.05 & 2.18, & 2.25 & 2.27, & 2.3 \\
\hline 2.60 & 1.50, & 1.61, & 1.61, & 1.7 \\
\hline 3.10 & 1.20 & 1.22, & 1.23, & 1.2 \\
\hline 3.70 & 1.03, & 1.05, & 1.07, & 1.0 \\
\hline 4.40 & 1.02, & 1.03, & 1.08 & 1.1 \\
\hline
\end{tabular}

1-benzoyl-2-furfurylidenehydrazine の各 $\mathrm{pH}$ に数ける水溶液中の反応は, furfurylidene-INAH にくらべて 見掛けの速度は早く, $\mathrm{pH} 4.28$ 飞预いて平衡に達する時間は 3 時間かかるが，それ以下の $\mathrm{pH}$ では 1 時間以内 に平衡に達する。

各 $\mathrm{pH}$ 亿和故る測定した平衡恒数を Table VI 示す. furfurylidene-INAH, 1-benzoyl-2-furfurylidenehydrazine はいずれも $\mathrm{pH} 4$ 以上では平衡恒数は添ぼ一定になり，それ以下では水素イオンの增大とともに大きくな る. 
Table VI. Reiationship between $\mathrm{pH}$ and $\mathrm{K}$ in 1-Benzoyl-2-Furfurylidenehydrazine in Buffer Solution

\begin{tabular}{lrrr}
$\mathrm{pH}$ & \multicolumn{3}{c}{$\mathrm{K}\left(\times 10^{-4}\right)$} \\
1.57 & 11.28, & 11.30, & 11.24 \\
2.02 & 5.42, & 5.32, & 5.36 \\
2.48 & 2.48, & 2.47, & 2.49 \\
3.18 & 1.15, & 1.12, & 1.13 \\
3.82 & 0.82, & 0.88, & 0.86 \\
4.28 & 0.72, & 0.71, & 0.72
\end{tabular}

\section{INAH-hydrazone の水溶液中における平衡の機構}

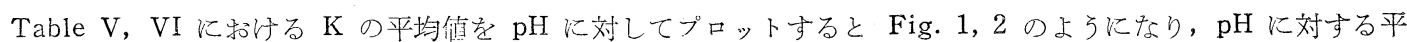
衡恒数の变化はほぼ同じ状態を示す。

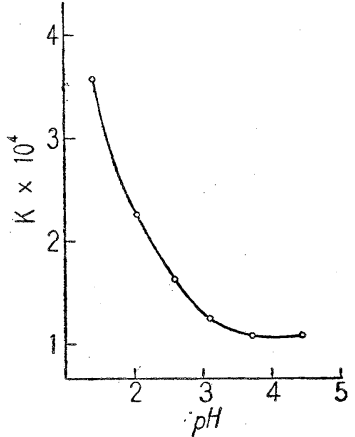

Fig. 1. Variation in Equilibrium Constant of Furfurylidene-INAH with $\mathrm{pH}$ at $30^{\circ}$

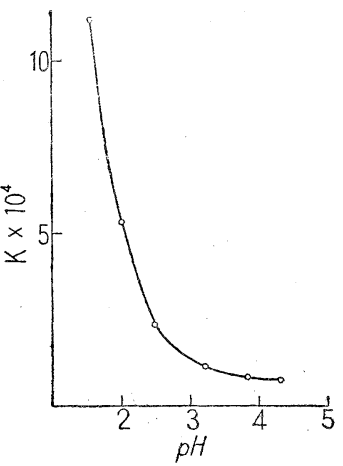

Fig. 2. Variation of Equilibrium Constant of 1-Benzoyl-2-furfurylidenehydrazine with $\mathrm{pH}$ at $30^{\circ}$

1-benzoyl-2-furfurylidenehydrazine 水溶液の pH K対する平衡の機構は Conant らの結論と同じものと考 えられるから, furfurylidene-INAH の場合も共鳴構造の变化による平衡への影響は直接には無いように思われる。 これを確認するために以下の計算を行つた。すなわち(II) 式から最小自乗法で $\mathrm{K}_{\mathrm{A}}$ ， $\mathrm{K}_{\mathrm{S}}$ を算出すると(V)（VI) 式となる。

$$
\begin{aligned}
& \mathrm{K}_{\mathrm{A}}=\mathrm{K}_{0}\left\{\sum\left[\mathrm{H}^{+}\right]^{2} \cdot \sum \mathrm{K}^{2} \cdot[\mathrm{H}+]^{2}-\left\{\sum \mathrm{K} \cdot\left[\mathrm{H}^{+}\right]^{2}\right\}^{2}\right\} /\left\{\mathrm{K}_{0} \sum \mathrm{K} \cdot[\mathrm{H}+] \cdot \sum \mathrm{K} \cdot\left[\mathrm{H}^{+}\right]^{2}+\sum \mathrm{K}^{2} \cdot\left[\mathrm{H}^{+}\right]^{2} \cdot \sum \mathrm{K} \cdot[\mathrm{H}+]\right\} \\
& -\left\{\sum \mathrm{K} \cdot[\mathrm{H}+]^{2} \cdot \sum \mathrm{K}^{2} \cdot[\mathrm{H}+]+\mathrm{K}_{0} \sum[\mathrm{H}+] \cdot \sum \mathrm{K}^{2}[\mathrm{H}+]^{2}\right\} \\
& \mathrm{K}_{\mathrm{S}}=\left\{\sum \mathrm{K}^{2} \cdot\left[\mathrm{H}^{+}\right]^{2} \cdot \sum[\mathrm{H}+]^{2}-\left\{\sum \mathrm{K} \cdot\left[\mathrm{H}^{+}\right]^{2}\right\}^{2}\right\} /\left\{\sum \mathrm{K} \cdot[\mathrm{H}+]^{2} \cdot \sum \mathrm{K} \cdot[\mathrm{H}+]+\mathrm{K}_{0} \cdot \sum\left[\mathrm{H}^{+}\right]^{2} \cdot \sum \mathrm{K} \cdot[\mathrm{H}+]\right. \\
& \left.-\mathrm{K}_{0} \sum \mathrm{K} \cdot\left[\mathrm{H}^{+}\right]^{2} \cdot \sum\left[\mathrm{H}^{+}\right]-\sum\left[\mathrm{H}^{+}\right]^{2} \cdot \sum \mathrm{K}^{2}\left[\mathrm{H}^{+}\right]\right\}
\end{aligned}
$$

(V)，(VI) 式に Table V, VI をむてはめて furfurylidene-INAH, 1-benzoyl-2-furfurylidenehydrazineの $\mathrm{K}_{\mathrm{S}}$ INAH, benzoylhydrazine の $\mathrm{K}_{\mathrm{A}}$ を算出すると Table VII のようになる。

Table VII. Calculated Values of Ks and Ka by Least Squares Method

$\begin{array}{llll} & \text { Ks } & & \text { Ka } \\ \text { Furfurylidene-INAH } & 1.87 \times 10^{-2} & \text { INAH } & 0.42 \times 10^{-2} \\ \text { 1-Benzoyl-2-furfurylidenehydrazine } & 6.44 " \prime & \text { Benzoylhydrazine } & 0.13 " \text { " }\end{array}$

Table VII の $\mathrm{K}_{\mathrm{A}}, \mathrm{K}_{\mathrm{S}}$ から測定した $\mathrm{pH}$ に和ける平衡衙恒数を算出して測定値にくらべると Table VIII の ようになる。

実験值と計算值は誤差範囲内でよく一致し, furfurylidene-INAH 扝よび 1-benzoyl-2-furfurylidenehydrazine の水溶液中に打兴加水分解生成物との間の平衡は pHによつて差があり，液の水素イオン濃度と平衡恒数の関係 は (II) 式によることを明らかにし得た。この結果から furfurylidene-INAH に怙ける pyridine 部への proton 付加は平衡恒数に直接影響なく， azometine 基への塩基性に効果を持つのみだと考えられる。 
Table VIII. Comparison between Observed and Calculated K-Values in Furfurylidene-INAH and 1-Benzoyl-2-furfurylidenehydrazine at Different $\mathrm{pH}$ Value of Buffer Solution at $30 \pm 1^{\circ}$

Furfurylidene-INAH

$\begin{array}{cl}\mathrm{pH} & \text { Obsvd. } \\ 1.42 & 3.55 \times 10^{-4} \\ 2.05 & 2.25 \prime \prime \\ 2.60 & 1.61 " \\ 3.10 & 1.23 \prime \prime\end{array}$

1-Benzoyl-2-furfurylidenehydrazine $\mathrm{pH}$

1.57

2.02

2.48

3.18

3.82
Obsvd.

$11.27 \times 10^{-4}$

$5.37 \quad$ "

$2.48 \quad \prime$

1.13 "

0.87 "
Calcd.

$3.55 \times 10^{-4}$

2.27 "

$1.51 " \prime$

1.11 "

Calcd.

$11.24 \times 10^{-4}$

5.38 "

2.47

1.13 "

$0.85 \prime \prime$

Table VII に括いて $\mathrm{K}_{\mathrm{A}}$ が benzoylhydrazine より.INAH の大きいのは, 塩基性の強い pyridine 部に proton が付加するのでその electron attracting な性質が強くなり，カルボニルの， 位の窒素の電子密度が benzoylhydrazine にくらべて減少しているためだと考え得る。 また $\mathrm{K}_{\mathrm{S}}$ は逆に 1-benzoyl-2-furfurylidenehydrazine の方が大きい， $\mathrm{K}_{\mathrm{S}}$ が $\mathrm{K}_{\mathrm{A}}$ にくらべて大きいのは分子全体に共斬が成立し，しかも electron attracting なカルボ ニルのために, azometine 基の窒素の電子密度が減少したためであるが, furfurylidene-INAH で第 1 ～2 報で 述べたように pyridine 部の窒素への proton 付加によつてアミドの部位で共䡉が遮断され, 1-benzoyl-2-furfurylidenehydrazine ほどカルボニル基と $\beta$ 位の窒素との間の共鳴効果が少なくないために azometine 基の窒 素の電子密度の減少効果が少くなったためである.

平衡恒数は正逆両反応の速度恒数の比で表わされる. しかも正逆両反応とも反応部位の電子密度の大きい活ど速 度が大きいことは小の semicarbazone の転移状態执よび Conantらの oxime, hydrazone 反応速度の結 果からも推論される。著者の実験でも pH 4 以上で benzoylhydrazine の方が INAH よりも平衡に至る速度が 速いのはこの推論を裹付けている。 なた furfurylidene-INAH の方が 1-benzoyl-2-furfurylidenehydrazine よ りも大きい $K_{0}$ 值を示すのは (1) 式に扩る正反応の比速度 (INAH の速度に対する benzoylhydrazine の速度 の比）が逆反応の比速度よりも大きいためであるとしてこれを説明し得る。

終りに御鞭撻を賜つた研究所長桑田 智博士, 部長渡辺厚博士に謹謝し, 有力な御助言定賜わつた山岸正治博士, 神沢得之助博士に樑謝す。また実験に協力された岡本千鶴子孃に感謝する。

\section{実験 の 部}

\section{INAH（ヌは benzoylhydrazine）の定量}

試 薬 a) NQS 試薬：NQS Na 塩 $50 \mathrm{mg}$ 打よび $\mathrm{Na}_{2} \mathrm{SO}_{4} 500 \mathrm{mg}$ を水 $50 \mathrm{cc}$ 飞溶かす。 b) pH 10 の Menzel buffer ${ }^{8)}$.

定量法 共栓試験管 3 本に試料（所定の緩衝液に反応系学溶解したもの)，標準液（INAH（又はbenzoyl-

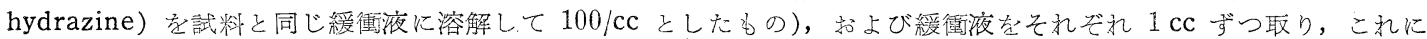
NQS 試薬 $0.5 \mathrm{cc}$ 抢よび Menzel buffer $5 \mathrm{cc}$ 加え，2〜3 分間放置，その hydrazine では $450 \mathrm{~m} \mu$ ) 学測定し, 次式から試料中の INAH の濃度を算出する.

$$
\begin{aligned}
& \text { concn. of INAH }(\gamma / \mathrm{cc})=100 \frac{\mathrm{A}-\mathrm{C}}{\mathrm{B}-\mathrm{C}} \\
& \mathrm{A} \text { : 試料の } \varepsilon \text {-value } \\
& \mathrm{B} \text { : 標準液 " } \\
& \mathrm{C} \text { : 緩衛液 " }
\end{aligned}
$$

定量法の検討 さきに著者は $2 N \mathrm{NaOH}$ を缏用して定量したが，この場合呈色夜が不安定で時間に上る変化が速い ので pH 10 の Menzel buffer に改めた。また化学平衡を検討する場合には種々の $\mathrm{pH}$ の緩衝液にINAHなぞ の反㐫系を溶解したものを用いるが，本法によるINAH の呈色度は緩衝液の $\mathrm{pH}$ につて差が現われる。 故に標淮液は試料と同一の緩衙液を使用しなければならない。

7) 小方芳郎“物理有機化学解説” 331 頁.

8) Menzel: Z. Physik. Chem. 100, 276 (1921). 
Table.IX,Fig. 3 は pH 3.10 の緩衙液に怙ける検量線であるが，この結果から誤差を計算すると变動係数とし て $1.08 \%$ になる.

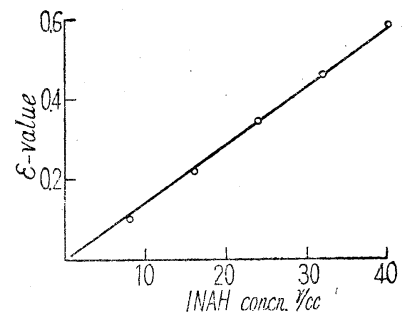

Table IX. Relationship between Concentrations of INAH and $\varepsilon$-Value in NQS Method

$\begin{array}{cc}\text { Concn. of INAH } & \varepsilon \text {-Value } \\ 30 \gamma / \mathrm{cc} & 0.583 \\ 32 & 0.463 \\ 24 & 0.350 \\ 16 & 0.225 \\ 8 & 0.115\end{array}$

Fig. 3. Determination Curve of INAH

本法を平衡恒数の測定に用いるためには反応系の他の化合物 2-furaldehyde 打よび furfurylidene-INAH が呈 色試薬と何等の作用もしないこと名必要でめる。著者は 2-furaldehyde の $500 \mathrm{\gamma} / \mathrm{cc}$ の液について本法に従つて操 作したが全く呈色しなかつた。また furfurylidene-INAH の $450 \gamma / \mathrm{cc}$ の水溶液については調製後ただちに本法に よる反応存行わせ，時間によるその -value の变化を測定した (Table X).

Table X. Effect of Furfurylidene-INAH in NQS Method

\begin{tabular}{|c|c|c|}
\hline Tim & fter reaction & $\varepsilon \cdot V$ alue \\
\hline 0 & nute & 0.003 \\
\hline 3 & $\prime \prime$ & 0.003 \\
\hline 10 & $\prime \prime$ & 0.005 \\
\hline 15 & $\prime \prime$ & 0.008 \\
\hline 30 & $\prime \prime$ & 0.022 \\
\hline 60 & $\prime \prime$ & 0.060 \\
\hline $\mathrm{bl}$ & & 0.003 \\
\hline
\end{tabular}

Table X:から furfurylidene-INAH は時間の経過とともに分解して INAH が生成し，呈色度は強くなるが， 10 分以内に $\varepsilon$-value を測定すれば，湮とんぞ影響のないことがわかる。

benzoylhydrazine はINAH と全く同様の方法で定量される. benzoylhydrazineをアルカリ性で NQS 試薬と 反応呈色させたときの吸収スペクトルはFig. 4 のようになり，吸収極大が $450 \mathrm{~m} \mu$ にあるので 長で測定する必要がある。检量線はFig. 5 に示すように直線となる。

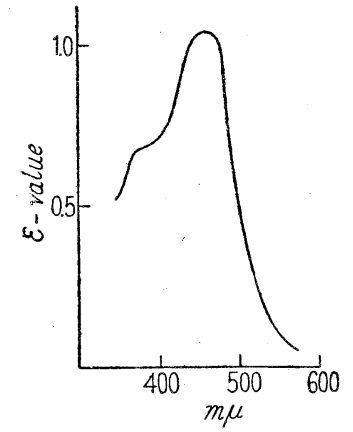

Fig. 4. Absorption Spectrum of Colored Solution of Benzoylhydrazine

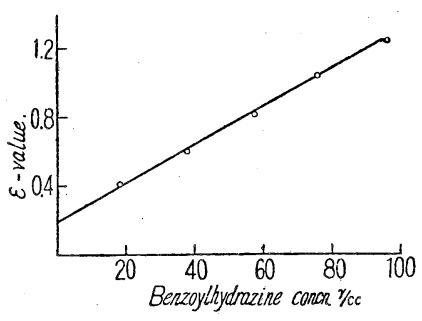

Fig. 5. Determination Curve of Benzoylhydrazine

\section{平衡恒数の測定}

試 料 2-furaldehyde, INAH, benzoylhydrazine, furfurylidene-INAH：いずれも前報記載のものを用いた， buffer：反広中に $\mathrm{pH}$ の移動による平衡の変化の防止拈上び緩衝液成分一定にするために Britton, Robinson 9) の 㽻域緩衝液の浱度を変えて用いた。すなおち $\mathrm{H}_{3} \mathrm{PO}_{4}, \mathrm{AcOH}$ および $\mathrm{H}_{3} \mathrm{BO}_{3}$ の $0.2 M$ の混液 $100 \mathrm{cc} k \mathrm{pH}$ を調 節するため $N$ NaOH を若干加光全量を $200 \mathrm{cc} と し ，$ 所定の $\mathrm{pH}$ の緩衝液を調製する。

9) Britton, Robinson: J. Chem. Soc. 1931, 485. 
測定法 2-furaldehyde 括よび INAH（または benzoylhydrazine）または furfurylidene-INAH（または 1ー benzoyl-2-furfurylidenehydrazine) 在所定の緩衝液に溶解して $3 \sim 4 \times 10^{-4} M$ の濃度となし，これを電気恒温水 槽に大れて $30 \pm 1^{\circ}$ で反応させ， 30 分ないし 1 時間ごとに取り出して反応系の INAH の定量を行う。この系が平 衡に達するとINAH の定量值が一定になるからこの定量值を平衡時のINAH の濃度とする。

平衡恒数の計算には (VII) 式を用いだ.

$\mathrm{K}=[2$-furaldehyde concn. $M][\mathrm{INAH}$ concn. $M] /[$ furfurylidene-INAH concn. $M] \cdots \cdots$ (VII)

furfurylidene-INAH から出発した場合の (VII) 式による $\mathrm{K} の$ 算出は平衡成立時に [2-furaldehyde concn. $M$ ] $=[\mathrm{INAH}$ concn. $M]$ であるから，その時のINAH の定量值から (VII) 式に打ける分子が計算され，分母はfurfurylidene-INAH の初濃度と平衡成立時の INAH の濃度の差から算出される。一方 2-furaldehyde, INAH 混液 から出発して平衡恒数を求める場合には INAH の初濃度と定量した平衡時の INAH 濃度の差が furfurylideneINAH の平衡時の濃度となり，2-furaldehyde の初濃度と算出した furfurylidene-INAH の濃度の差が平衡時の 2-furaldehyde の濃度になるからこれらの值から平衡恒数を算出し得る。

武田薬品工業株式会社研究所

UDC $547.826 .1-574.3: 541.122$

210. 藤原 洋：イソニコチン酸ヒドラジド誘導体の理化学的研究（第 5 報）イソニコチン酸 ヒドラジド誘導体の水溶液中の化学平衡について その 2

Hiroshi Fujiwara: Physicochemical Studies on Isonicotinoylhydrazine Derivatives V. On Equilibrium of Isonicotinoylhydrazine Derivatives in Aqueous Solutions. (2).

(Research Laboratories, Takeda Pharmacentical Industries, Ltd.)

\begin{abstract}
in order to elucidate equilibrium mechanism of hydrolysis in aqueous solution of $p$ amino- and $p$-dimethylamino-benzylidene-INAH, equilibrium constants were measured in buffer solutions of various $\mathrm{pH}$. It was thereby clarified that the relationship between $\mathrm{pH}$ and equilibrium constants does not satisfy the known Conant formula, that the basicity of the aldehyde also affected these constants, and that an entirely new relative formula (VII) had to be forwarded.
\end{abstract}

(Received February 28, 1958)

前報で著者は 1-furfurylidene-2-isonicotinoylhydrazine (furfurylidene-INAH) を水溶液中で加水分解した ときの平衡の機構を㠰明し，平衡恒数は液の $\mathrm{pH}$ の影響を受け，その関係は Conant の式で表わされることを明 らかにした。香た第 3 報で $p$-dimethylaminobenzylidene-INAH， p-aminobenzylidene-INAH のような強い electron releasing な置換基を持つた benzylidene-INAH 誘導体が塩を形成するとき proton が azometine 基 に付加することを明らかにした。 isonicotinoylhydrazone（以下 INAH-hydrazone と略）の水溶液中に新省化 学平衡について azometine 基の塩基性が重大な役割を演ずることは Conant の式から明膫であるが，p-dimethylaminobenzaldehyde, $p$-aminobenzaldehyde なぞは塩基性を持つのでその平衡の機構には Conant 式以上の複 雑さがあるだろう・本報で著者はこれらの INAH-hydrazone の平衡の機構についてて検討し，全く新しい機構に よることを明らか沉し得た。

著者はこれら化合物の平衡恒数を後述（実験の部）の方法で測定し，測定範囲内で INAH の一定値を得，平衡 の成立を認めた。すなおちこの反応系沈和ける他の副反応として考えられるものにアルデヒド拉よび INAH の分 解、アルデヒド相互の反応などがある。これらの副反応が不可逆的であるならば平衡恒数の測定で INAHの一定 值が得られないはずである。しかし副反応が可逆的の場合にはこれのみで判定することはできない。著者はこのよ うな副反応としてアルデヒドの縮合の可能性があると推定し，平衡恒数の測定と同一条件でアルデヒドの安定度を 検討した. p-dimethylaminobenzaldehyde については pH 0.5 および 5 ，p-aminobenzaldehyde そついては 